\title{
Synthesis and Cytotoxic Activity Study of Novel 2-(Aryldiazenyl)-3-methyl-1H-benzo[g]indole Derivatives
}

\author{
Manar M. Arafeh ${ }^{1}$, Ebrahim Saeedian Moghadam ${ }^{2}$, Sirin A. I. Adham ${ }^{3}{ }^{\circ}$, Raphael Stoll ${ }^{4}$ \\ and Raid J. Abdel-Jalil $2, *$ (D) \\ 1 Faculty of Pharmacy, Middle East University, Amman 11831, Jordan; manararafeh@yahoo.com \\ 2 Chemistry Department, College of Science, Sultan Qaboos University, Muscat 123, Oman; \\ saeedian1985@gmail.com \\ 3 Biology Department, College of Science, Sultan Qaboos University, Muscat 123, Oman; sadham@squ.edu.om \\ 4 Biomolecular NMR, Ruhr University of Bochum, D-44780 Bochum, Germany; \\ raphael.stoll@ruhr-uni-bochum.de \\ * Correspondence: jalil@squ.edu.om
}

check for updates

Citation: Arafeh, M.M.; Moghadam, E.S.; Adham, S.A.I.; Stoll, R.; Abdel-Jalil, R.J. Synthesis and Cytotoxic Activity Study of Novel 2-(Aryldiazenyl)-3methyl- $1 H$-benzo $[g]$ indole Derivatives. Molecules 2021, 26, 4240. https://doi.org/10.3390/ molecules 26144240

Academic Editor: Alexander F. Khlebnikov

Received: 18 June 2021

Accepted: 4 July 2021

Published: 12 July 2021

Publisher's Note: MDPI stays neutral with regard to jurisdictional claims in published maps and institutional affiliations.

Copyright: (c) 2021 by the authors. Licensee MDPI, Basel, Switzerland. This article is an open access article distributed under the terms and conditions of the Creative Commons Attribution (CC BY) license (https:/ / creativecommons.org/licenses/by/ $4.0 /)$.

\begin{abstract}
A novel series of 2-(aryldiazenyl)-3-methyl-1H-benzo[ $g$ ]indole derivatives (3a-f) were prepared through the cyclization of the corresponding arylamidrazones, employing polyphosphoric acid (PPA) as a cyclizing agent. All of the compounds (3a-f) were characterized using ${ }^{1} \mathrm{H} \mathrm{NMR}$, ${ }^{13} \mathrm{C}$ NMR, MS, elemental analysis, and melting point techniques. The synthesized compounds were evaluated for cytotoxic activity against diverse human cancer cell lines by the National Cancer Institute. While all of the screened compounds were found to be cytotoxic at a $10 \mu \mathrm{M}$ concentration, two of them (2c) and (3c) were subjected to five dose screens and showed a significant cytotoxicity and selectivity.
\end{abstract}

Keywords: anti-cancer; synthesis; indole; heterocycles

\section{Introduction}

Cancer is a serious threat to human beings; from the medical viewpoint, it is a complicated complex of genetic diseases, including abnormal and uncontrolled cell growth and proliferation, with the potential to spread throughout the body. Currently, great efforts are being made to prevent or diminish cancer incidence and increase its treatment efficacy, but unfortunately, cancer is still a major cause of morbidity and mortality worldwide and the second most frequent cause of death in the United States.

Combination chemotherapy using antineoplastic agents with a different mechanism of action is one potential approach used to combat cancer [1]. However, the significant drug resistance and narrow dosing window of these drugs, combined with a lack of selectivity, decrease the efficacy of cancer chemotherapy. Thus, incorporating two functional groups in a single molecule, each with a different mechanism of action, might enhance cancer treatment. These limitations in cancer chemotherapy using the currently available drugs encourage drug discovery researchers to find new efficient chemotherapeutic agents for cancer treatment [2]. Nitrogen-containing heterocyclic compounds are a class of compounds that have recently attracted an increased interest within the pharmaceutical community due to their widespread and often diverse biological activities [3]. The indolebased compounds in particular are common building blocks for many medicinally active drugs and are considered as target pharmacophores for the development of therapeutic agents [4-9]. During the last decade, various benzo[ $g$ ]indoles have been synthesized and found to exhibit a broad spectrum of biological activities, among which the interchelating anti-tumor activity is of considerable pharmaceutical interest [10]. Certain benzoindoles are useful structures with interesting bioactivities, such as LOX inhibition, bromodomain and extra-terminal (BET) inhibition, anticancer effects, non-covalent Keap1-Nrf2 protein-protein 
interaction inhibition, and microsomal prostaglandin E2 synthase-1 inhibition [11-20]. The incorporation of azo moiety as a structural motif has enhanced the cytotoxicity of various systems [21,22]. Ross and Warwick synthesized some azobenzenes which were reduced selectively in vivo to the corresponding diamine and are good alkylating agents [23].

In order to combine the features of two of the most important drug classes in cancer therapy, interchelating and alkylating agents, we report here the synthesis of a new series of 2-(aryldiazenyl)-3-methyl-1H-benzo[ $g]$ indoles and their anti-tumor activities.

\section{Results and Discussion}

\subsection{Synthesis of Benzo[g]indoles}

The general synthetic pathway is shown in Scheme 1. The 1-arylhydrazono-1-chloroace tones (1) were prepared from readily available substituted anilines and $\alpha$-chloroacetylacetone using a standard method [24], which involves the diazotization of the substituted anilines with sodium nitrite in situ, followed by coupling with $\alpha$-chloroacetylacetone to give the desired 1-arylhydrazono-1-chloroacetones (1a-f) in a 70-80\% yield. The 1-arylhydrazono-1chloroacetones (1a-f) were then coupled with 1-naphthylamine to yield the corresponding arylamidrazones (2a-f), which are then cyclized using polyphosphoric acid (PPA) as a catalyst to produce benzo[ $g]$ indole target products (3a-f) in a 50-60\% yield.

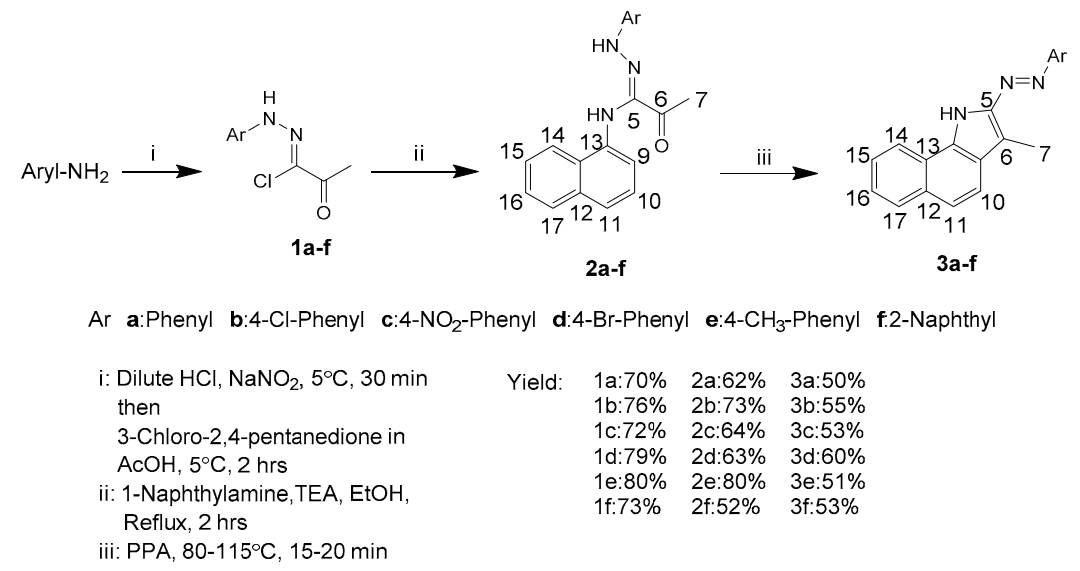

Scheme 1. Synthetic pathway to obtain the target compounds $3 \mathbf{a}-\mathbf{f}$.

The synthetic pathway illustrated here has several important advantages. First of all, it represents a fairly straightforward, three-step procedure, which employs readily available starting materials, leading to benzo $[g]$ indole derivatives (3a-f) in good yields. At the same time, a range of derivatives are readily available for each of the starting materials, which subsequently allows for chemical diversification at each step of the synthesis. These considerations particularly apply to the substituted anilines, which are used as part of the first and the second step of the synthesis.

The ${ }^{1} \mathrm{H}$ NMR spectra of arylamidrazones (2a-f) show two doublets at $\delta(8.1-8.2) \mathrm{ppm}$ and $\delta$ (7.9-8.1) ppm assigned to the two protons, $\mathrm{H}-14$ and $\mathrm{H}-17$ (as numbered in Scheme 1), which appear as the most de-shielded protons, with a coupling constant in the range of $6.7-9.0 \mathrm{~Hz}$ for $\mathrm{H}-14$ and $6.4-8.2 \mathrm{~Hz}$ for $\mathrm{H}-17$. The methyl protons resonate around $\delta 2.6-2.8 \mathrm{ppm}$ as sharp singlets. The H-9 protons appear as the most upfield protons among the aromatic signals due to the anisotropic effect of the adjacent carbonyl group or imine functional group and appear as doublets at around $\delta 6.0-6.5 \mathrm{ppm}$, with a coupling constant of $7.3 \mathrm{~Hz}$. In the ${ }^{13} \mathrm{C}$ NMR spectra, the methyl carbons resonate in the range of $\delta 23.8-24.0 \mathrm{ppm}$, while the carbonyl carbon resonates at around $\delta 194.1-194.5 \mathrm{ppm}$. The carbons in the imine bonds $C=\mathrm{N}$ carbons resonate in the range of $\delta 137.8-147.9 \mathrm{ppm}$. Aromatic carbons resonate at around $\delta 108.7-137.2 \mathrm{ppm}$.

The combined use of 2D homo and hetero-nuclear chemical shift correlation spectroscopy (H/H COSY, C/H COSY, and HMBC) allowed for the unambiguous and complete 
assignment of the proton and carbon chemical shifts of the target benzo[ $[g]$ indoles (3a-f). In the ${ }^{1} \mathrm{H}$ NMR spectra of $(3 \mathbf{a}-\mathbf{f})$, the exchangeable $\mathrm{N}-\mathrm{H}$ protons resonate in the range of $\delta$ 9.5-9.7 ppm and appear as broad singlets. The methyl protons resonate at around $\delta 2.7-2.8 \mathrm{ppm}$, and they appear as sharp singlets. The $\mathrm{H}-10$ protons appear in the most de-shielded region among the aromatic protons, and they appear as doublets at around $\delta 7.9-8.1 \mathrm{ppm}$, with a coupling constant of $6.4-8.2 \mathrm{~Hz}$. In the ${ }^{13} \mathrm{C}$ NMR spectra of the benzoindoles, methyl carbons resonate in the range of $8.6-8.9 \mathrm{ppm}$, and C-5 resonate at around $\delta 151.5-165.2 \mathrm{ppm}$.

\subsection{Cytotoxic Activity Screening}

The benzo[g]indoles synthesized in this study were considered for anti-cancer activity screening, as part of the developmental therapeutics program of the National Cancer Institute (NCI) [25-27]. After the primary cytotoxic activity screening of all the synthesized compounds, the benzo[ $g]$ indoles, (3a) and (3c), were selected for in-depth studies, together with their arylamidrazone precursors, (2a) and (2c), respectively. As part of these tests, a comprehensive screen against 60 different cancer cell lines was performed, which includes various cell lines representative of non-small cell lung cancer, colon cancer, breast cancer, ovarian cancer, leukemia, renal cancer, melanoma, prostate cancer, and cancer of the central nervous system (CNS).

The results for each compound are reported as the growth percentage (GP) of treated cells in comparison to those untreated control cells. The growth percentage values at a single dose of $10 \mu \mathrm{M}$ for 60 cancer cell lines are shown in Table 1. Overall, four tested compounds were found to be cytotoxic at $\mu \mathrm{M}$ concentrations $\left(\mathrm{GI}_{50}\right.$ and $\mathrm{LC}_{50}$ concentrations of around $10 \mu \mathrm{M}$ ). This toxicity is not unusual, since benzoindoles are known to affect cell survival and proliferation [28]. Interestingly, the screening also revealed that apart from the active benzo $[g]$ indoles, (3a) and (3c), their precursors, i.e., the arylamidrazones (2a) and (2c), were also cytotoxic, albeit with a different target cell specificity. Furthermore, a rather unexpected activity was found for compounds (2c) and (3c), as they showed a growth reduction equal to or less than $50 \%$ in the initial one-dose analysis. These compounds were selected for further evaluation in the full panel of 60 human tumor cell lines using five different concentrations, and the negative growth present value represents the highest activity of the compound.

Table 1. Percentage of growth in the presence of the selected compounds $(\mathbf{2 a}, \mathbf{2 c}, \mathbf{3 a}$, and $\mathbf{3 c})$ and its absence (control) on sixty subpanel cell lines at a single concentration of $10 \mu \mathrm{M}$.

\begin{tabular}{ccccc}
\hline \multirow{2}{*}{ Panel/Cell Line } & \multicolumn{4}{c}{ Growth Percent } \\
\cline { 2 - 5 } & 2a & 2c & 3a & 3c \\
\hline A549/ATCC & 69.44 & 84.26 & 92.54 & 80.09 \\
\hline EKVX & 76.03 & 78.76 & 73.09 & 74.93 \\
\hline HOP-62 & 81.34 & 51.51 & 29.60 & 25.91 \\
\hline HOP-92 & 33.21 & 35.72 & 60.21 & 44.83 \\
\hline NCI-H226 & 99.51 & 92.05 & 99.78 & 100.75 \\
\hline NCI-H23 & 73.65 & 64.91 & 84.97 & 78.89 \\
\hline NCI-H322M & 91.49 & 105.11 & 97.36 & 68.40 \\
\hline NCI-H460 & 75.61 & 94.59 & 94.86 & 72.23 \\
\hline NCI-H522 & 75.81 & 54.91 & 91.34 & 73.86 \\
\hline
\end{tabular}


Table 1. Cont.

\begin{tabular}{|c|c|c|c|c|}
\hline \multirow{2}{*}{ Panel/Cell Line } & \multicolumn{4}{|c|}{ Growth Percent } \\
\hline & $2 \mathbf{a}$ & $2 c$ & $3 a$ & $3 c$ \\
\hline \multicolumn{5}{|c|}{ Colon cancer } \\
\hline COLO 205 & 14.30 & 99.52 & 94.11 & 103.74 \\
\hline HCC 2998 & 96.18 & 104.22 & 112.55 & 82.06 \\
\hline HCT-116 & 57.79 & 31.85 & 81.24 & 36.33 \\
\hline НСТ-15 & 83.87 & 63.16 & 93.35 & 97.05 \\
\hline HT29 & 90.12 & 71.13 & 95.74 & 63.32 \\
\hline KM12 & 73.78 & 72.32 & 94.26 & 55.31 \\
\hline SW-620 & 86.13 & 83.69 & 89.85 & 92.36 \\
\hline \multicolumn{5}{|c|}{ Breast cancer } \\
\hline BT-549 & 103.70 & 89.37 & 106.49 & 85.34 \\
\hline HS 578T & 93.72 & 86.11 & 99.28 & 47.64 \\
\hline MCF7 & 82.09 & 62.01 & 75.06 & 73.52 \\
\hline $\begin{array}{c}\text { MDA- } \\
\text { MB231/ATCC }\end{array}$ & 67.35 & 18.85 & 75.32 & 51.11 \\
\hline MDA-MB-435 & 73.89 & 89.88 & 117.26 & 79.44 \\
\hline NCI/ADR-RES & 79.52 & 53.56 & 97.52 & 57.70 \\
\hline T-47D & 77.39 & 57.95 & 57.02 & 65.60 \\
\hline \multicolumn{5}{|c|}{ Ovarian cancer } \\
\hline IGROV1 & 46.54 & 28.70 & 55.11 & n.d \\
\hline OVCAR-3 & 80.17 & 70.33 & 113.38 & 83.26 \\
\hline OVCAR-4 & 83.45 & 58.02 & 76.65 & 58.59 \\
\hline OVCAR-5 & 87.30 & 101.63 & 74.65 & 91.62 \\
\hline OVCAR-8 & 80.46 & 56.55 & 85.78 & 42.45 \\
\hline SK-OV-3 & 91.80 & 86.27 & 56.87 & 56.47 \\
\hline \multicolumn{5}{|c|}{ Leukemia } \\
\hline CCRF-CEM & n.d & n.d & 55.11 & n.d \\
\hline HL-60 (TB) & 98.62 & 63.94 & 113.38 & 65.44 \\
\hline K-562 & 81.97 & 61.96 & 76.40 & 52.58 \\
\hline MOLT-4 & 70.05 & 30.61 & 74.65 & 68.43 \\
\hline RPMI-8226 & 101.28 & 55.40 & 85.78 & 41.72 \\
\hline SR & 52.89 & 44.50 & 56.87 & 42.01 \\
\hline \multicolumn{5}{|c|}{ Renal cancer } \\
\hline $786-0$ & 92.49 & 42.69 & 96.80 & 33.52 \\
\hline A498 & 79.07 & 86.05 & 102.61 & 104.03 \\
\hline $\mathrm{ACHN}$ & 79.25 & 84.86 & 91.60 & 59.22 \\
\hline CAKI-1 & 73.31 & 85.31 & 92.56 & 65.21 \\
\hline RXF-393 & 82.22 & 67.14 & 91.82 & 56.38 \\
\hline SN12C & 82.55 & 86.62 & 125.05 & 66.78 \\
\hline TK-10 & 118.78 & 133.33 & 121.64 & 51.66 \\
\hline UO-31 & 50.27 & 41.83 & 71.11 & 30.48 \\
\hline
\end{tabular}


Table 1. Cont.

\begin{tabular}{|c|c|c|c|c|}
\hline \multirow{2}{*}{ Panel/Cell Line } & \multicolumn{4}{|c|}{ Growth Percent } \\
\hline & $2 a$ & $2 c$ & $3 a$ & $3 c$ \\
\hline \multicolumn{5}{|c|}{ Melanoma } \\
\hline LOX IMVI & 82.55 & 19.76 & 90.71 & 65.76 \\
\hline M14 & 96.72 & 81.03 & 105.14 & 88.37 \\
\hline MALME-3M & 107.30 & 88.02 & 98.42 & 54.84 \\
\hline SK-MEL-2 & 96.85 & 79.25 & 106.50 & 104.37 \\
\hline SKMEL-28 & 119.81 & 114.44 & 107.48 & 121.72 \\
\hline XKMEL-5 & 88.71 & 89.46 & 91.32 & 93.18 \\
\hline UACC-257 & 84.78 & 80.16 & 98.19 & 94.79 \\
\hline UACC-62 & 78.97 & 76.16 & 89.78 & 72.57 \\
\hline \multicolumn{5}{|c|}{ Prostate cancer } \\
\hline DU-145 & 107.24 & 94.77 & 98.36 & 66.38 \\
\hline PC-3 & 108.27 & 49.85 & 66.82 & 4.60 \\
\hline \multicolumn{5}{|c|}{ CNS cancer } \\
\hline SF-268 & 95.30 & 79.49 & 92.41 & 57.88 \\
\hline SF-295 & 49.59 & 87.95 & 89.78 & 82.65 \\
\hline SF-539 & 87.43 & 84.04 & 82.23 & 72.03 \\
\hline SNB-19 & 86.64 & 87.85 & 102.38 & 82.38 \\
\hline SNB-75 & 77.18 & 94.99 & 89.21 & 65.17 \\
\hline $\mathrm{U} 251$ & 90.64 & 74.01 & 100.46 & 44.23 \\
\hline Mean & 81.84 & 72.63 & 89.46 & 65.99 \\
\hline
\end{tabular}

A comparison of the values for growth percentage of inhibition of the two compounds, (2c) and (3c), at $100 \mu \mathrm{M}, \mathrm{GI} 50$, TGI, and LC50 are listed in Table 2. The arylamidrazone (2c) showed a considerable activity against two leukemia cancer cells, HL-60(TB) (GI50 equals to $3.9 \mu \mathrm{M}$ ) and MOLT-4 (GI50 equals to $2.3 \mu \mathrm{M}$ ), and also against the melanoma cell line, MALME-3M (GI50 of $5.44 \mu \mathrm{M}$ ), and the breast cancer cell line, HS 578T (GI50 of $6.05 \mu \mathrm{M})$. A better inhibition activity was observed for the corresponding benzo[ $g$ ]indole compound, (3c), at nano-molar concentrations, which was specifically active against leukemia cell lines: HL-60(TB) (GI50 of $560 \mathrm{nM}$ ). Apparently, the arylamidrazone inhibited cell growth considerably more effectively (close to $50 \%$ in MOLT- 4 cells (GP $=-42$ ), when compared to all the other cell lines investigated, pointing toward a better inhibition activity to leukemia cells (Table 2) (Figure 1). Compound (3c) was not only active and specific against the leukemia cell lines, but it also showed activity against the melanoma cell line, SK-MEL-5, with a GP $=-46$ (Table 2) at a $100 \mu \mathrm{M}$ concentration and a GI50 as low as $429 \mathrm{nM}$ (Figure 2). Not only leukemia or melanoma, but also two renal cancer cell lines are affected by the benzoindole (3c) A498 and RXF 393 cell lines, with a negative growth present value and a GI50 of $605 \mathrm{nM}$ and $336 \mathrm{nM}$, respectively. The most interesting inhibition activity was noticed against the HS 578T breast cancer cell line, derived from a rare, highly malignant mammary carcinosarcoma cell line, possessing histopathologic features of both carcinoma and sarcoma (bone cancer) [29,30]. This HS 578T cell line was inhibited by the maximum growth inhibition, when compared with the GI50s of the other cell lines, and the lowest recorded value by this compound was $53 \mathrm{nM}$, with a -44 value of growth inhibition (Figure 3). These values represent the lowest concentration of the compound. (3c) is therefore a very potent compound not only for leukemia, but also for breast cancer. Interestingly, compounds (2c) and (3c) contain the nitroaniline moiety, while 
the unsubstituted aniline compounds, (2a) and (3a), are less active and do not show a clear 'trend' or specificity as far as certain cancer cell lines are concerned.

Table 2. Comparison of $2 c$ and $3 c$ compounds, according to their growth present (GP), GI50 $(\mu M)$, TGI, and LC50 values at $100 \mu \mathrm{M}$.

\begin{tabular}{|c|c|c|c|c|c|c|c|c|}
\hline \multirow[b]{2}{*}{ Cell Line } & \multicolumn{4}{|c|}{$2 c$} & \multicolumn{4}{|c|}{$3 c$} \\
\hline & GP & $\mathrm{GI}_{50}$ & TGI & $\mathrm{LC}_{50}$ & GP & $\mathrm{GI}_{50}$ & TGI & $\mathrm{LC}_{50}$ \\
\hline \multicolumn{9}{|l|}{ Leukemia } \\
\hline CCRF-CEM & 13 & 8.2 & 50 & 50 & 5 & 0.486 & 25 & 25 \\
\hline $\mathrm{HL}-60(\mathrm{~TB})$ & -18 & 3.9 & 26.3 & 50 & -3 & 0.56 & 15.5 & 25 \\
\hline$K-562$ & 12.8 & 50 & 50 & 50 & 10 & 0.528 & 25 & 25 \\
\hline MOLT-4 & -16 & 2.3 & 21.4 & 50 & -42 & 0.373 & 1 & 25 \\
\hline RPMI-8226 & 24 & 3.91 & 50 & 50 & -6 & 0.382 & 4.13 & 25 \\
\hline SR & 42 & 23.3 & 50 & 50 & -28 & 0.32 & 1.29 & 25 \\
\hline \multicolumn{9}{|c|}{ Non-small cell lung cancer } \\
\hline A549/ATCC & 43 & 35.2 & 50 & 50 & 29 & 1.81 & 25 & 25 \\
\hline EKVX & 40 & 29.4 & 50 & 50 & 21 & 0.803 & 25 & 25 \\
\hline $\mathrm{HOP}-62$ & 63 & 50 & 50 & 50 & 26 & 1.95 & 25 & 25 \\
\hline HOP-92 & 49 & 45.8 & 50 & 50 & 25 & 0.973 & 25 & 25 \\
\hline NCI-H226 & 3 & 3.3 & 50 & 50 & 37 & 1.67 & 25 & 25 \\
\hline NCI-H23 & 24 & 12.5 & 50 & 50 & 36 & 1.92 & 25 & 25 \\
\hline NCI-H322M & 31 & 19 & 50 & 50 & 67 & 25 & 25 & 25 \\
\hline NCI-H460 & 24 & 19.5 & 50 & 50 & 17 & 1.21 & 25 & 25 \\
\hline \multicolumn{9}{|l|}{ Colon Cancer } \\
\hline COLO 205 & 72 & 50 & 50 & 50 & 21 & 1.12 & 25 & 25 \\
\hline HCC-2998 & 80 & 50 & 50 & 50 & 70 & 25 & 25 & 25 \\
\hline НCT-116 & 8 & 5.6 & 50 & 50 & 25 & 0.989 & 25 & 25 \\
\hline НCТ-15 & 42 & 12.2 & 50 & 50 & 29 & 0.711 & 25 & 25 \\
\hline HT29 & 6 & 12.6 & 50 & 50 & 12 & 0.727 & 25 & 25 \\
\hline KM12 & 12 & 11.3 & 50 & 50 & 24 & 1.63 & 25 & 25 \\
\hline SW -620 & 32 & 2.03 & 50 & 50 & 25 & 1.89 & 25 & 25 \\
\hline \multicolumn{9}{|l|}{ CNS cancer } \\
\hline SF-26836 & 18.8 & 50 & 50 & 50 & 40 & 2.35 & 25 & 25 \\
\hline $\mathrm{SF}-295-3$ & 8.7 & 45.9 & 50 & 50 & 4 & 0.997 & 25 & 25 \\
\hline$S F-53926$ & 15.2 & 50 & 50 & 50 & 36 & 1.16 & 25 & 25 \\
\hline SNB-19 & 56 & 50 & 50 & 50 & 44 & 2.75 & 25 & 25 \\
\hline $\mathrm{SNB}-75$ & 34 & 17.8 & 50 & 50 & 10 & 0.722 & 25 & 25 \\
\hline U25136 & 26 & 50 & 50 & 50 & 23 & 0.936 & 25 & 25 \\
\hline
\end{tabular}


Table 2. Cont.

\begin{tabular}{|c|c|c|c|c|c|c|c|c|}
\hline \multirow[b]{2}{*}{ Cell Line } & \multicolumn{4}{|c|}{$2 c$} & \multicolumn{4}{|c|}{$3 c$} \\
\hline & GP & $\mathrm{GI}_{50}$ & TGI & $\mathrm{LC}_{50}$ & GP & $\mathrm{GI}_{50}$ & TGI & $\mathrm{LC}_{50}$ \\
\hline \multicolumn{9}{|l|}{ Melanoma } \\
\hline LOX IMVI & 2 & 1.86 & 50 & 50 & 6 & 0.681 & 25 & 25 \\
\hline MALME-3M & -3 & 5.44 & 43.9 & 50 & 20 & 0.662 & 25 & 25 \\
\hline MDA-MB-4 & 35 & 9 & 14.2 & 50 & 18 & 1.1 & 25 & 25 \\
\hline SK-MEL-2 & 37 & 17.5 & 50 & 50 & 21 & 1.15 & 25 & 25 \\
\hline SK-MEL-28 & 65 & 50 & 50 & 50 & 6 & 0.689 & 25 & 25 \\
\hline SK-MEL-5 & 40 & 28.2 & 50 & 50 & -46 & 0.429 & 1.17 & 25 \\
\hline UACC -257 & 38 & 27.2 & 50 & 50 & 17 & 1.44 & 25 & 25 \\
\hline UACC -62 & 44 & 31.2 & 50 & 50 & 22 & 1.28 & 25 & 25 \\
\hline \multicolumn{9}{|l|}{ Ovarian } \\
\hline OVCAR-3 & 5 & 9.12 & 50 & 50 & 27 & 1.4 & 25 & 25 \\
\hline OVCAR -4 & 18 & 4.73 & 50 & 50 & 20 & 0.973 & 25 & 25 \\
\hline OVCAR -5 & 124 & 50 & 50 & 50 & 86 & 25 & 25 & 25 \\
\hline OVCAR-8 & 31 & 16.5 & 50 & 50 & 28 & 1.69 & 25 & 25 \\
\hline NCI/ADR-RES & 25 & 8.72 & 50 & 50 & 18 & 1.07 & 25 & 25 \\
\hline SK-OV-3 & 48 & 42.5 & 50 & 50 & 42 & 8.57 & 25 & 25 \\
\hline \multicolumn{9}{|l|}{ Renal Cancer } \\
\hline $786-0$ & 50 & 49.9 & 50 & 50 & 7 & 1.15 & 25 & 25 \\
\hline A498 & 23 & 15.7 & 50 & 50 & -14 & 0.605 & 22.4 & 25 \\
\hline $\mathrm{ACHN}$ & 40 & 26.5 & 50 & 50 & 24 & 0.997 & 25 & 25 \\
\hline CAKI-1 & 22 & 13.6 & 50 & 50 & 32 & 1.05 & 25 & 25 \\
\hline RXF 393 & 13 & 2.11 & 50 & 50 & -25 & 0.336 & 1.27 & 25 \\
\hline SN12C & 14 & 8.14 & 50 & 50 & 44 & 2.09 & 25 & 25 \\
\hline TK-10 & 46 & 44.4 & 50 & 50 & 60 & 25 & 25 & 25 \\
\hline UO-31 & 29 & 4.96 & 50 & 50 & 34 & 1.63 & 25 & 25 \\
\hline \multicolumn{9}{|l|}{ Prostate } \\
\hline PC3 & 29 & 10.2 & 50 & 50 & 14 & 0.515 & 25 & 25 \\
\hline DU-145 & 40 & 30.4 & 50 & 50 & 53 & 25 & 25 & 25 \\
\hline \multicolumn{9}{|l|}{ Breast } \\
\hline MCF7 & 4 & 6.42 & 50 & 50 & 11 & 0.704 & 25 & 25 \\
\hline MDA-231 & 10 & 3.15 & 50 & 50 & 20 & 0.94 & 25 & 25 \\
\hline HS 578T & -25 & 6.05 & 50 & 50 & -44 & 0.053 & 0.0479 & 25 \\
\hline BT -549 & 55 & 50 & 50 & 50 & 6 & 0.51 & 25 & 25 \\
\hline $\mathrm{T}-47 \mathrm{D}$ & 42 & 24.8 & 50 & 50 & 5 & 0.364 & 25 & 25 \\
\hline
\end{tabular}




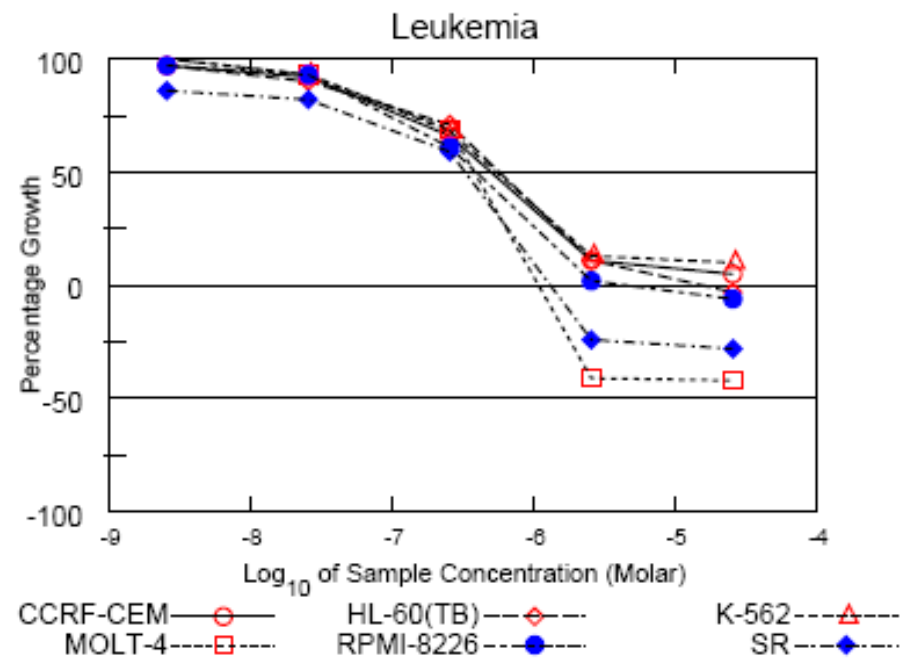

Figure 1. Data obtained from the NCI, showing that Leukemia MOLT4 has a negative GP $=-42$ and SR cell line GP $=-28$, after the addition of compound $3 c$.

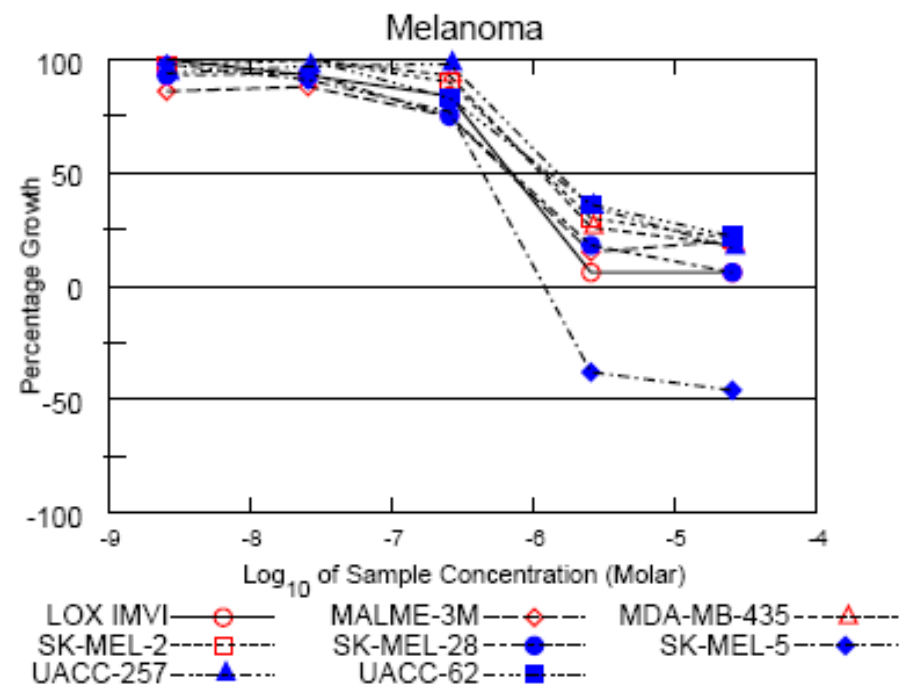

Figure 2. Compound $3 \mathrm{c}$ has affected the growth present of the melanoma cell line, SK-MEL-5, with a GP value of -46 .

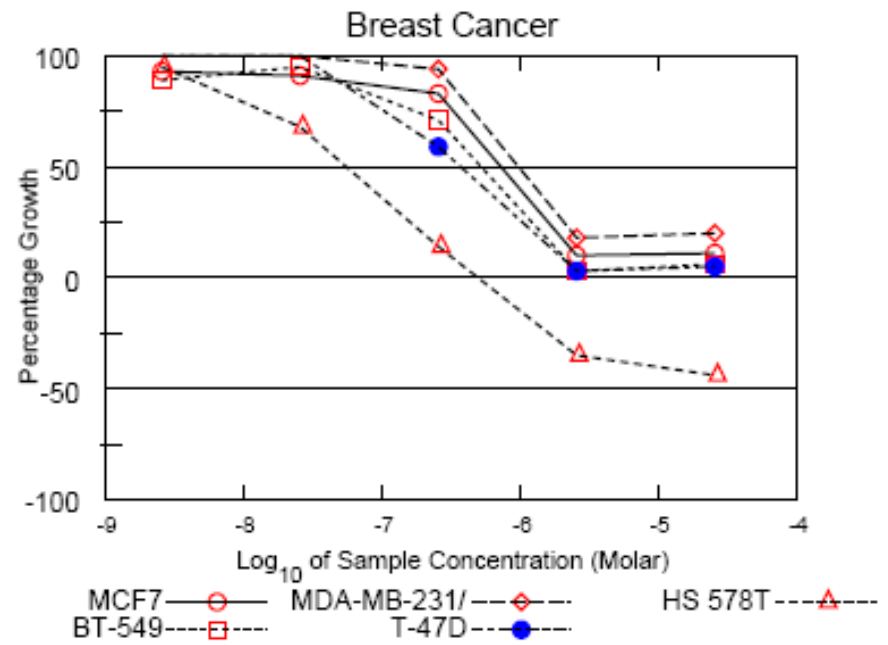

Figure 3. The effect of the 3c compound on the HS 578T breast cancer cell line, with a growth present of -44 . 
Nonetheless, as the arylamidrazone (2c) illustrates, the simple hydrophobic interaction with DNA strands or metabolic enzymes do not seem to be the only reason for cytotoxicity. Here, the azo group present in the benzo[g]indoles, as well as arylamidrazones, may play an additional role. This group is known to be metabolized readily, for instance, by Phase I enzymes in the liver, which leads us to the second possible cause of cytotoxicity. Hepatic azo-reduction is known to result in amine 'fragments' of the azo compound affected. Such a reduction is also possible for the compounds studied here, which may subsequently break down into smaller fragments-each of which may exhibit its own cytotoxicity. Interestingly, an azo reduction of the corresponding benzo[g]indoles and arylamidrazone may result in different, yet partially related 'fragments'.

Furthermore, benzene ring hydroxylation may occur, and peroxidases may generate fairly toxic ortho-quinones. Regardless of the precise metabolic events associated with such aromatic compounds, it is likely that such processes are cell type-specific, i.e., the generation of metabolites will differ in the kind and extent of metabolites, depending on the cell type [30]. It is therefore possible that leukemia cells are particularly prone to some of the compounds tested due to a specific metabolic 'activation' of these compounds in leukemia cells. This notion is, of course, speculative at this point and needs further investigation.

Finally, we also need to emphasize that the arylamidrazones, as precursors of the benzo $[g]$ indoles, possess a chemistry of their own, which differs from the one of their corresponding cyclization products. For instance, the arylamidrazone contains a highly reactive ketone, which is used in the cyclization process. This group may also react with biomolecules, leading up to modified proteins, enzymes, DNA, or RNA. The latter may show an impaired function and activity. If, and to what extent, such a chemistry occurs in the living cell is still unclear. Nonetheless, it provides an additional mode of action for the arylamidrazones that is worth considering in the future.

\section{Materials and Methods}

\subsection{Chemistry}

All chemicals, reagents, and solvents were bought from Sigma company and were used without further purification. The ${ }^{1} \mathrm{H}$ NMR spectra were recorded on a Bruker Unity 300 or $400 \mathrm{MHz}$ spectrometer. The ${ }^{13} \mathrm{C}$ NMR spectra were also recorded at 75 or $100 \mathrm{MHz}$. The chemical shifts are given in ppm and were referenced with the residual solvent resonances relative to tetramethylsilane (TMS). The mass spectra were obtained on a Finnigan MAT 312 mass spectrometer, connected to a PDO 11/34 (DEC) computer system by electron impact. The elemental analyses were determined using a Perkin Elmer Model 240-C instrument (PerkinElmer, Hopkinton, MA, USA). The melting points were measured on a SMP1 Stuart apparatus and are uncorrected. Flash chromatography was conducted using MERCK silica gel (mesh size 230-400 ASTM). Thin-layer chromatography (TLC) was performed on Macherey-Nagel poly gram Sil G/UV254 silica gel plates, with visualization under UV (254 nm).

\subsubsection{General Procedure for the Preparation of the 1-arylhydrazono-1-chloroacetone (1a-f)}

At first, the related aromatic amine $(5 \mathrm{mmol})$ was dissolved in dilute hydrochloric acid $(10 \mathrm{~mL})$, and then a solution of sodium nitrite $(6 \mathrm{mmol})$ in water $(5 \mathrm{~mL})$ was added dropwise at $5{ }^{\circ} \mathrm{C}$. After completing the addition, the mixture was stirred for an extra $30 \mathrm{~min}$. Then, 3-Chloro-2,4-pentandione $(5 \mathrm{mmol})$ in acetic acid $(3 \mathrm{~mL})$ was added to the primary mixture, and the reaction mixture was left to stir at $5{ }^{\circ} \mathrm{C}$ for $2 \mathrm{~h}$. After the completion of the reaction, detected by TLC, the produced solid was filtered, washed with cold water, and dried under vacuum overnight. The collected solid 1 was used directly for the next step, without further purification and characterization [24]. 
3.1.2. General Procedure for the Preparation of

1-(naphthylamino)-1-(arylhydrazono)-2-propanone (2a-f)

To a stirred solution of 1-arylhydrazono-1-chloroacetone $1(10 \mathrm{mmol})$ and 1-naphthyla mine $(10 \mathrm{mmol})$ in ethanol $(10 \mathrm{~mL})$, triethylamine (TEA) $(2 \mathrm{~mL})$ was added at room temperature. The reaction mixture was refluxed for $2 \mathrm{hrs}$ and cooled, and water was added $(30 \mathrm{~mL})$. The resulting precipitate was filtered off. The product was recrystallized from hot ethanol to yield the corresponding arylamidrazone 2.

$N$-(Naphthalen-1-yl)-2-oxo- $N^{\prime}$-phenylpropanehydrazonamide (2a)

Yield 62\%; m.p. $148-150{ }^{\circ} \mathrm{C} ;{ }^{1} \mathrm{H}$ NMR $\left(250 \mathrm{MHz}, \mathrm{CDCl}_{3}\right): \delta=2.67\left(\mathrm{~s}, 3 \mathrm{H}, \mathrm{CH}_{3}\right), 8.10(\mathrm{~d}$, $\mathrm{JH}, \mathrm{H}=9.8 \mathrm{~Hz}, 1 \mathrm{H}, \mathrm{H}-14), 7.88$ (d, JH,H = 7.0 Hz, $1 \mathrm{H}, \mathrm{H}-17), 7.51-7.62$ (m, $3 \mathrm{H}, \mathrm{H}-11, \mathrm{H}-15$, H-16), 7.21-7.34 (m, 5 H, H-2, H-2', H-3, H-3', H-4), 6.90-7.04 (m, 3 H, H-10, NH, *NH), $6.32(\mathrm{~d}, \mathrm{JH}, \mathrm{H}=7.32 \mathrm{~Hz}, 1 \mathrm{H}, \mathrm{H}-9) \mathrm{ppm} .{ }^{13} \mathrm{C} \mathrm{NMR}\left(75.5 \mathrm{MHz}, \mathrm{CDCl}_{3}\right): \delta=23.9\left(\mathrm{CH}_{3}\right)$, $143.0(\mathrm{C}=\mathrm{N}), 194.3(\mathrm{C}=\mathrm{O}), 113.2(\mathrm{C}-9), 113.7\left(\mathrm{C}-2 \backslash \mathrm{C}-2^{\prime}\right), 121.9$ (C-14), $123.0(\mathrm{C}-10), 133.2$ (C-3 \C-3'), 129.3 (C-17), 125.5, 126.2, 126.4, 128.6, 134.5, 135.3. MS: $m / z(\%)=303(100)$

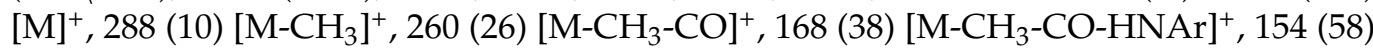
$\left[\mathrm{M}-\mathrm{CH}_{3}-\mathrm{CO}-\mathrm{HNAr}-\mathrm{N}\right]^{+}, 143$ (42) [M-CH$\left.{ }_{3}-\mathrm{CO}-\mathrm{HNAr}-\mathrm{N}-\mathrm{C}+\mathrm{H}\right]^{+} . \mathrm{C}_{19} \mathrm{H}_{17} \mathrm{~N}_{3} \mathrm{O}$ (303.36): calcd. C 75.23, H 5.65, N 13.85; found C 75.36, H 5.53, N 13.98.

$N^{\prime}$-(4-Chlorophenyl)- $N$-(naphthalen-1-yl)-2-oxopropanehydrazonamide (2b)

Yield 73\%; m.p. $134-136{ }^{\circ} \mathrm{C} ;{ }^{1} \mathrm{H}$ NMR $\left(300 \mathrm{MHz}, \mathrm{CDCl}_{3}\right): \delta=2.64\left(\mathrm{~s}, 3 \mathrm{H}, \mathrm{CH}_{3}\right), 8.12(\mathrm{~d}$, $\mathrm{JH}, \mathrm{H}=9.0 \mathrm{~Hz}, 1 \mathrm{H}, \mathrm{H}-14), 7.93(\mathrm{~d}, \mathrm{JH}, \mathrm{H}=7.5 \mathrm{~Hz}, 1 \mathrm{H}, \mathrm{H}-17), 7.62$ (m, $3 \mathrm{H}, \mathrm{H}-11, \mathrm{H}-15, \mathrm{H}-16)$, 7.40 (br. s, $1 \mathrm{H}, \mathrm{NH}), 7.35$ (dd, JH,H = 6.0 Hz, $1 \mathrm{H}, \mathrm{H}-10), 7.22(\mathrm{~d}, \mathrm{JH}, \mathrm{H}=6.0 \mathrm{~Hz}, 2 \mathrm{H}, \mathrm{H}-3 / \mathrm{H}-$ 3'), 7.13 (br. s, $\left.1 \mathrm{H},{ }^{*} \mathrm{NH}\right), 6.97\left(\mathrm{~d}, \mathrm{JH}, \mathrm{H}=6.0 \mathrm{~Hz}, 2 \mathrm{H}, \mathrm{H}-2 / \mathrm{H}-2^{\prime}\right), 6.35(\mathrm{~d}, \mathrm{JH}, \mathrm{H}=6.0 \mathrm{~Hz}$, $1 \mathrm{H}, \mathrm{H}-9)$ ppm. ${ }^{13} \mathrm{C}$ NMR $\left(75.5 \mathrm{MHz}, \mathrm{CDCl}_{3}\right): \delta=23.9\left(\mathrm{CH}_{3}\right), 141.7(\mathrm{C}=\mathrm{N}), 194.2(\mathrm{C}=\mathrm{O})$, 113.4 (C-9), 114.8 (C-2 \C-2'), 121.7 (C-14), 123.3 (C-10), 129.3 (C-3\C-3'), 128.7 (C-17), 125.4, 126.3, 126.5, 126.6, 132.9, 134.5. MS: $m / z(\%)=337(73)[\mathrm{M}]^{+}, 322(26)\left[\mathrm{M}^{-} \mathrm{CH}_{3}\right]^{+}, 294(22)$ $\left[\mathrm{M}-\mathrm{CH}_{3}-\mathrm{CO}\right]^{+}, 168$ (58) [M-CH $\left.3-\mathrm{CO}-\mathrm{HNAr}\right]^{+}, 154$ (100) [M-CH $\left.\mathrm{CH}_{3}-\mathrm{CO}-\mathrm{HNAr}-\mathrm{N}\right]^{+}, 143$ (52) [M- $\left.\mathrm{CH}_{3}-\mathrm{CO}-\mathrm{HNAr}-\mathrm{N}-\mathrm{C}+\mathrm{H}\right]^{+} . \mathrm{C}_{19} \mathrm{H}_{16} \mathrm{ClN}_{3} \mathrm{O}$ (337.80): calcd. C 67.56, $\mathrm{H} 4.77, \mathrm{~N}$ 12.44; found $\mathrm{C} 68.05, \mathrm{H} 4.80, \mathrm{~N} 12.68$.

$N$-(Naphthalen-1-yl)- $N^{\prime}$-(4-nitrophenyl)-2-oxopropanehydrazonamide (2c)

Yield 64\%; m.p. $180-182{ }^{\circ} \mathrm{C} ;{ }^{1} \mathrm{H}$ NMR $\left(300 \mathrm{MHz}, \mathrm{CDCl}_{3}\right): \delta=2.73\left(\mathrm{~s}, 3 \mathrm{H}, \mathrm{CH}_{3}\right), 8.11-8.16$ (m, $3 \mathrm{H}, \mathrm{H}-11, \mathrm{H}-15, \mathrm{H}-16), 7.94$ (d, JH,H = 9.3 Hz, $1 \mathrm{H}, \mathrm{H}-14), 7.61-7.73$ (m, $3 \mathrm{H}, \mathrm{H}-17$, $\mathrm{H}-10, \mathrm{NH}), 7.57$ (br. s, $\left.1 \mathrm{H},{ }^{*} \mathrm{NH}\right), 7.37$ (d, JH,H = 7.2 Hz, $\left.2 \mathrm{H}, \mathrm{H}-3 \backslash \mathrm{H}-3^{\prime}\right), 6.97$ (d, JH,H $\left.=9.3 \mathrm{~Hz}, 2 \mathrm{H}, \mathrm{H}-2 \backslash \mathrm{H}-2^{\prime}\right), 6.47(\mathrm{~d}, \mathrm{JH}, \mathrm{H}=7.5 \mathrm{~Hz}, 1 \mathrm{H}, \mathrm{H}-9) \mathrm{ppm} .{ }^{13} \mathrm{C} \mathrm{NMR}(75.5 \mathrm{MHz}$, $\left.\mathrm{CDCl}_{3}\right): \delta=24.0\left(\mathrm{CH}_{3}\right), 147.9(\mathrm{C}=\mathrm{N}), 194.3(\mathrm{C}=\mathrm{O}), 112.8(\mathrm{C}-9), 114.9\left(\mathrm{C}-2 \backslash \mathrm{C}-2^{\prime}\right), 132.5(\mathrm{C}-$ $\left.3 \backslash \mathrm{C}-3^{\prime}\right), 124.4$ (C-10), 121.7 (C-14), 128.8 (C-17), 125.2, 125.9, 126.5, 126.7, 126.8, 134.5, 137.1. MS: $m / z(\%)=348(55)[\mathrm{M}]^{+}, 333(6)\left[\mathrm{M}^{-\mathrm{CH}_{3}}\right]^{+}, 305$ (10) [M-CH3-CO] ${ }^{+}, 168$ (50) $\left[{\mathrm{M}-\mathrm{CH}_{3}-}^{-}\right.$ $\mathrm{CO}-\mathrm{HNAr}]^{+}, 154$ (100) [M-CH $\left.{ }_{3}-\mathrm{CO}-\mathrm{HNAr}-\mathrm{N}\right]^{+}, 143$ (33) [M-CH$\left.{ }_{3}-\mathrm{CO}-\mathrm{HNAr}-\mathrm{N}-\mathrm{C}+\mathrm{H}\right]^{+}$. $\mathrm{C}_{19} \mathrm{H}_{16} \mathrm{~N}_{4} \mathrm{O}_{3}$ (348.36): calcd. C 65.51, H 4.63, N 16.08; found C 66.10, H 4.63, N 16.01.

$N^{\prime}$-(4-Bromophenyl)- $N$-(naphthalen-1-yl)-2-oxopropanehydrazonamide (2d)

Yield 63\%; m.p. $138-140{ }^{\circ} \mathrm{C} ;{ }^{1} \mathrm{H}$ NMR $\left(400 \mathrm{MHz}, \mathrm{CDCl}_{3}\right): \delta=2.66(\mathrm{~s}, 3 \mathrm{H}, \mathrm{CH} 3), 8.09(\mathrm{~d}$, $\mathrm{JH}, \mathrm{H}=8.1 \mathrm{~Hz}, 1 \mathrm{H}, \mathrm{H}-14), 7.89$ (d, JH,H = 7.6 Hz, $1 \mathrm{H}, \mathrm{H}-17)$ 7.54-7.61 (m, $3 \mathrm{H}, \mathrm{H}-11, \mathrm{H}-15$, $\mathrm{H}-16), 7.38$ (br. s, $1 \mathrm{H}, \mathrm{NH}), 7.30-7.34$ (m, $3 \mathrm{H}, \mathrm{H}-10, \mathrm{H}-3 \backslash \mathrm{H}-3$ '), 7.13 (br. s, $1 \mathrm{H},{ }^{*} \mathrm{NH}$ ), $6.89\left(\mathrm{~d}, \mathrm{JH}, \mathrm{H}=8.8 \mathrm{~Hz}, 2 \mathrm{H}, \mathrm{H}-2 \backslash \mathrm{H}-2^{\prime}\right), 6.32(\mathrm{~d}, \mathrm{JH}, \mathrm{H}=7.3 \mathrm{~Hz}, 1 \mathrm{H}, \mathrm{H}-9)$ ppm. ${ }^{13} \mathrm{C} \mathrm{NMR}$ $\left(100.6 \mathrm{MHz}, \mathrm{CDCl}_{3}\right): \delta=23.9\left(\mathrm{CH}_{3}\right), 142.1(\mathrm{C}=\mathrm{N}), 194.2(\mathrm{C}=\mathrm{O}), 113.8(\mathrm{C}-9), 115.6\left(\mathrm{C}-2 \backslash \mathrm{C}-2^{\prime}\right)$, 132.5 (C-3 \C-3'), 123.7 (C-10), 129.1 (C-17), 122.1 (C-14), 125.8, 126.4, 126.7, 126.9, 133.3,

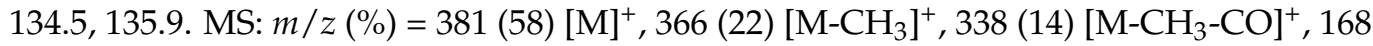
(62) $\left[\mathrm{M}-\mathrm{CH}_{3}-\mathrm{CO}-\mathrm{HNAr}\right]^{+}, 154$ (100) [M-CH$\left.{ }_{3}-\mathrm{CO}-\mathrm{HNAr}-\mathrm{N}\right]^{+}, 143$ (69) $\left[\mathrm{M}-\mathrm{CH}_{3}-\mathrm{CO}-\mathrm{HNAr}-\right.$ $\mathrm{N}-\mathrm{C}+\mathrm{H}]^{+} . \mathrm{C}_{19} \mathrm{H}_{16} \mathrm{BrN}_{3} \mathrm{O}$ (382.25): calcd. C 59.70, $\mathrm{H}$ 4.22, N 10.99; found C 59.53, $\mathrm{H}$ 4.17, $\mathrm{N} 11.02$.

$N$-(Naphthalen-1-yl)-2-oxo- $N^{\prime}$-( $p$-tolyl)propanehydrazonamide (2e) 
Yield 80\%, m.p. $144-146{ }^{\circ} \mathrm{C} ;{ }^{1} \mathrm{H}$ NMR $\left(400 \mathrm{MHz}, \mathrm{CDCl}_{3}\right): \delta=2.66\left(\mathrm{~s}, 3 \mathrm{H}, \mathrm{CH}_{3}\right), 2.28$ $\left(\mathrm{s}, 3 \mathrm{H},{ }^{*} \mathrm{CH}_{3}\right), 8.10(\mathrm{~d}, \mathrm{JH}, \mathrm{H}=8.1 \mathrm{~Hz}, 1 \mathrm{H}, \mathrm{H}-14), 7.87(\mathrm{~d}, \mathrm{JH}, \mathrm{H}=8.8 \mathrm{~Hz}, 1 \mathrm{H}, \mathrm{H}-17)$, 7.50-7.60 (m, $3 \mathrm{H}, \mathrm{H}-11, \mathrm{H}-15, \mathrm{H}-16), 7.27-7.31$ (m, $2 \mathrm{H}, \mathrm{H}-10, \mathrm{NH}), 7.17$ (br. s, $\left.1 \mathrm{H},{ }^{*} \mathrm{NH}\right)$, $7.05\left(\mathrm{~d}, \mathrm{JH}, \mathrm{H}=8.3 \mathrm{~Hz}, 2 \mathrm{H}, \mathrm{H}-3 \backslash \mathrm{H}-3^{\prime}\right), 6.93\left(\mathrm{~d}, \mathrm{JH}, \mathrm{H}=8.3 \mathrm{~Hz}, 2 \mathrm{H}, \mathrm{H}-2 \backslash \mathrm{H}-2^{\prime}\right), 6.28(\mathrm{~d}$, $\mathrm{JH}, \mathrm{H}=7.3 \mathrm{~Hz}, 1 \mathrm{H}, \mathrm{H}-9) \mathrm{ppm} .{ }^{13} \mathrm{C} \mathrm{NMR}\left(100.6 \mathrm{MHz}, \mathrm{CDCl}_{3}\right): \delta=23.8\left(\mathrm{CH}_{3}\right), 140.8(\mathrm{C}=\mathrm{N})$, 194.1 (C=O), 113.3 (C-9), 114.1 (C-2 \C-2'), 130.2 (C-3 \C-3'), 123.2 (C-10), 129.0 (C-17), 122.1 (C-14), 125.9, 126.3, 126.5, 128.6, 131.9, 134.9. MS: $m / z(\%)=317(100)[\mathrm{M}]^{+}, 302(38)$ $\left[\mathrm{M}-\mathrm{CH}_{3}\right]^{+}, 274(26)\left[{\mathrm{M}-\mathrm{CH}_{3}-\mathrm{CO}}^{+}, 168 \text { (30) [M-CH}{ }_{3}-\mathrm{CO}-\mathrm{HNAr}\right]^{+}, 154$ (52) [M-CH 3 -COHNAr-N] ${ }^{+}, 143$ (57) [M-CH $\left.{ }_{3}-\mathrm{CO}-\mathrm{HNAr}-\mathrm{N}-\mathrm{C}+\mathrm{H}\right]^{+} . \mathrm{C}_{20} \mathrm{H}_{19} \mathrm{~N}_{3} \mathrm{O}$ (317.38): calcd. C 75.69, H 6.03, N 13.24; found C 77.45, H 6.05, N 13.00.

$N$-(Naphthalen-1-yl)- $N^{\prime}$-(naphthalen-2-yl)-2-oxopropanehydrazonamide (2f)

Yield 52\%; m.p. $162-164{ }^{\circ} \mathrm{C} ;{ }^{1} \mathrm{H}$ NMR $\left(250 \mathrm{MHz}, \mathrm{CDCl}_{3}\right): \delta=2.75\left(\mathrm{~s}, 3 \mathrm{H}, \mathrm{CH}_{3}\right), 8.23(\mathrm{~d}$, $\mathrm{JH}, \mathrm{H}=9.0 \mathrm{~Hz}, 1 \mathrm{H}, \mathrm{H}-18), 7.05$ (d, JH,H = 6.0 Hz, $1 \mathrm{H}, \mathrm{H}-8), 6.61$ (m, $2 \mathrm{H}, \mathrm{H}-2, \mathrm{H}-13)$, 7.28-7.79 (m, $12 \mathrm{H}) \mathrm{ppm} .{ }^{13} \mathrm{C}$ NMR $\left(75.5 \mathrm{MHz}, \mathrm{CDCl}_{3}\right): \delta=24.0\left(\mathrm{CH}_{3}\right), 137.8(\mathrm{C}=\mathrm{N})$, 194.5 (C=O), 137.8, 136.5, 134.6, 134.1, 133.0, 128.8, 128.6, 126.8, 126.6, 126.5, 126.3, 125.8, $125.6,125.5,123.9,122.4,122.1,121.8,118.9,115.2,108.7 \mathrm{ppm}$. MS: $m / z(\%)=353(100)$ $[\mathrm{M}]^{+}, 338(36)\left[\mathrm{M}-\mathrm{CH}_{3}\right]^{+}, 310$ (19) $\left[\mathrm{M}-\mathrm{CH}_{3}-\mathrm{CO}\right]^{+}, 168$ (29) $\left[\mathrm{M}-\mathrm{CH}_{3}-\mathrm{CO}-\mathrm{HNAr}\right]^{+}, 143$ (84) [M-CH $3-\mathrm{CO}-\mathrm{HNAr}-\mathrm{N}-\mathrm{C}+\mathrm{H}]^{+} . \mathrm{C}_{23} \mathrm{H}_{19} \mathrm{~N}_{3} \mathrm{O}$ (353.42): calcd. C 78.16, $\mathrm{H} 5.42, \mathrm{~N} 11.89$; found C 78.22, H 5.31, N 11.70.

3.1.3. General Procedure for the Synthesis of 2-(Aryldiazenyl)-3-methyl-1H-benzo[ $g]$ indoles (3a-f)

The corresponding 1-(naphthylamino)-1-(arylhydrazono)-2-propanone 2 (1 mmol) was added to PPA (4 g). The reaction mixture was heated to $80^{\circ} \mathrm{C}$ with stirring. Once the exothermic phase subsided, the temperature was increased further to $115^{\circ} \mathrm{C}$ to complete the reaction for another 15-20 min. The dark colored solution was then poured onto ice water $(50 \mathrm{~mL})$, and the resulting mixture was neutralized with ammonium hydroxide solution $(10 \mathrm{~mL}, 30 \%)$. The resulting solution was exhaustively extracted with diethylether $(10 \mathrm{~mL} \times 3)$. The combined organic extracts were dried using sodium sulfate, and the solvent was removed under vaccuum. The crude products were subsequently purified by preparative silica gel thin-layer chromatography, using DCM as the eluent.

3-Methyl-2-(phenyldiazenyl)- $1 H$-benzo[ $g$ ]indole (3a)

Yield 50\%; m.p. $174-176{ }^{\circ} \mathrm{C} ;{ }^{1} \mathrm{H} \mathrm{NMR}\left(400 \mathrm{MHz}, \mathrm{CDCl}_{3}\right): \delta=2.69\left(\mathrm{~s}, 3 \mathrm{H}, \mathrm{CH}_{3}\right), 9.56$ (br. s, NH), $7.98(\mathrm{~d}, \mathrm{JH}, \mathrm{H}=7.8 \mathrm{~Hz}, 1 \mathrm{H}, \mathrm{H}-10), 7.85\left(\mathrm{~d}, \mathrm{JH}, \mathrm{H}=7.6 \mathrm{~Hz}, 2 \mathrm{H}, \mathrm{H}-2 \backslash \mathrm{H}-2^{\prime}\right), 7.81(\mathrm{~d}$, $\mathrm{JH}, \mathrm{H}=7.6 \mathrm{~Hz}, 1 \mathrm{H}, \mathrm{H}-14), 7.61(\mathrm{~d}, \mathrm{JH}, \mathrm{H}=8.6 \mathrm{~Hz}, 1 \mathrm{H}, \mathrm{H}-17), 7.39-7.47$ (m, 5 H, H-11, H-15, H-16, H-3, H-3'), 7.33 (dd, JH,H = 7.2 Hz, $1 \mathrm{H}, \mathrm{H}-4)$ ppm. ${ }^{13} \mathrm{C}$ NMR (100.6 MHz, $\mathrm{CDCl}_{3}$ ): $\delta=9.1\left(\mathrm{CH}_{3}\right), 119.8(\mathrm{C}-17), 121.5(\mathrm{C}-10), 122.4\left(\mathrm{C}-2 \backslash \mathrm{C}-2^{\prime}\right), 129.5(\mathrm{C}-14), 130.2(\mathrm{C}-4), 153.4$ (C-5), 121.4, 121.9, 122.7, 125.2, 126.3, 132.1, 133.4, 145.2 ppm. MS: $m / z(\%)=285(100)[\mathrm{M}]^{+}$, 194 (6) [M-ArN] ${ }^{+}, 180$ (38) [M-ArN $]^{+} . \mathrm{C}_{19} \mathrm{H}_{15} \mathrm{~N}_{3}$ (285.34): calcd. C 79.98, H 5.30, N 14.73; found C 79.13, H 5.36, N 14.58.

2-((4-Chlorophenyl)diazenyl)-3-methyl-1H-benzo[ $g]$ indole (3b)

Yield 55\%; m.p. $181-183{ }^{\circ} \mathrm{C} ;{ }^{1} \mathrm{H}$ NMR $\left(400 \mathrm{MHz}, \mathrm{CDCl}_{3}\right): \delta=2.74\left(\mathrm{~s}, 3 \mathrm{H}, \mathrm{CH}_{3}\right), 9.57$ (br. s, $\mathrm{NH}), 8.04(\mathrm{~d}, \mathrm{JH}, \mathrm{H}=7.8 \mathrm{~Hz}, 1 \mathrm{H}, \mathrm{H}-10), 7.88(\mathrm{~d}, \mathrm{JH}, \mathrm{H}=7.6 \mathrm{~Hz}, 1 \mathrm{H}, \mathrm{H}-14), 7.85$ (d, JH,H = $\left.8.6 \mathrm{~Hz}, 2 \mathrm{H}, \mathrm{H}-2 \backslash \mathrm{H}-2^{\prime}\right), 7.67(\mathrm{~d}, \mathrm{JH}, \mathrm{H}=8.9 \mathrm{~Hz}, 1 \mathrm{H}, \mathrm{H}-17), 7.44-7.54$ (m, $5 \mathrm{H}, \mathrm{H}-11, \mathrm{H}-15$, H-16, H-3, H-3') ppm. ${ }^{13} \mathrm{C}$ NMR (100.6 MHz, $\left.\mathrm{CDCl}_{3}\right): \delta=9.1$ (CH3), 119.8 (C-17), 121.4 (C-10), 123.9 (C-2 \C-2'), 129.5 (C-14), 151.9 (C-5), 121.6, 121.8, 123.1, 125.3, 126.4, 126.5, 129.7, 132.4, 133.5, 135.7, 145.1 ppm. MS: $m / z(\%)=319(100)[\mathrm{M}]^{+}, 194(5)[\mathrm{M}-\mathrm{ArN}]^{+}, 180$ (34) $\left[\mathrm{M}-\mathrm{ArN}_{2}\right]^{+}$. $\mathrm{C}_{19} \mathrm{H}_{14} \mathrm{ClN}_{3}$ (319.79): calcd. C 71.36, $\mathrm{H} 4.41, \mathrm{~N}$ 13.14; found C 71.23, H 4.45, N 12.96 .

3-Methyl-2-((4-nitrophenyl)diazenyl)-1H-benzo[g]indole (3c) 
Yield 53\%; m.p. $182-184{ }^{\circ} \mathrm{C} .{ }^{1} \mathrm{H} \mathrm{NMR}\left(300 \mathrm{MHz}, \mathrm{CDCl}_{3}\right): \delta=2.81$ (s, $\left.3 \mathrm{H}, \mathrm{CH}_{3}\right), 9.64$ (br. s, $\mathrm{NH}), 8.36\left(\mathrm{~d}, \mathrm{JH}, \mathrm{H}=9.2 \mathrm{~Hz}, 2 \mathrm{H}, \mathrm{H}-2 \backslash \mathrm{H}-2^{\prime}\right), 8.11(\mathrm{~d}, \mathrm{JH}, \mathrm{H}=7.0 \mathrm{~Hz}, 1 \mathrm{H}, \mathrm{H}-10), 8.01$ (d, $\left.\mathrm{JH}, \mathrm{H}=9.2 \mathrm{~Hz}, 2 \mathrm{H}, \mathrm{H}-3 \backslash \mathrm{H}-3^{\prime}\right), 7.91(\mathrm{~d}, \mathrm{JH}, \mathrm{H}=9.5 \mathrm{~Hz}, 1 \mathrm{H}, \mathrm{H}-14), 7.70$ (d, JH,H = $8.5 \mathrm{~Hz}, 1$ $\mathrm{H}, \mathrm{H}-17), 7.49-7.59$ (m, $3 \mathrm{H}, \mathrm{H}-11, \mathrm{H}-15, \mathrm{H}-16)$ ppm. ${ }^{13} \mathrm{C} \mathrm{NMR}\left(75.5 \mathrm{MHz}, \mathrm{CDCl}_{3}\right): \delta=8.9$ $\left(\mathrm{CH}_{3}\right), 119.4$ (C-17), 121.2 (C-10), 124.9 (C-2 $\left.\backslash \mathrm{C}-2^{\prime}\right), 146.5$ (C-5), 121.8, 122.6 126.3, 126.9, 129.3, 135.2 ppm. MS: $m / z(\%)=330(100)[\mathrm{M}]^{+}, 194(9)[\mathrm{M}-\mathrm{ArN}]^{+}, 180$ (32) $\left[\mathrm{M}-\mathrm{ArN}_{2}\right]^{+}$. $\mathrm{C}_{19} \mathrm{H}_{14} \mathrm{~N}_{4} \mathrm{O}_{2}$ (330.34): calcd. C 69.08, H 4.27, N 16.96; found C 70.22, H 4.33, N 17.01.

2-((4-Bromophenyl)diazenyl)-3-methyl-1H-benzo[g]indole (3d)

Yield 60\%; m.p. $184-186{ }^{\circ} \mathrm{C} ;{ }^{1} \mathrm{H}$ NMR $\left(400 \mathrm{MHz}, \mathrm{CDCl}_{3}\right): \delta=2.69$ (s, $\left.3 \mathrm{H}, \mathrm{CH}_{3}\right), 9.54$ (br. s, $\mathrm{NH}), 8.02$ (d, JH,H = 7.8 Hz, $1 \mathrm{H}, \mathrm{H}-10), 7.83$ (d, JH,H = 7.6 Hz, 1 H, H-14), 7.73 (d, JH,H $\left.=8.8 \mathrm{~Hz}, 2 \mathrm{H}, \mathrm{H}-2 \backslash \mathrm{H}-2^{\prime}\right), 7.63(\mathrm{~d}, \mathrm{JH}, \mathrm{H}=8.8 \mathrm{~Hz}, 1 \mathrm{H}, \mathrm{H}-17), 7.56(\mathrm{~d}, \mathrm{JH}, \mathrm{H}=8.9 \mathrm{~Hz}, 2 \mathrm{H}$, H-3 \H-3'), 7.42-7.50 (m, 3 H, H-11, H-15, H-16) ppm. ${ }^{13} \mathrm{C}$ NMR (100.6 MHz, $\left.\mathrm{CDCl}_{3}\right): \delta=9.1$ $\left(\mathrm{CH}_{3}\right), 119.8$ (C-2\C-2'), $121.4(\mathrm{C}-10), 126.5$ (C-3\C-3'), 132.7 (C-17), 151.8 (C-5), 121.7, 124.1, 126.4, 129.6 ppm. MS: $m / z(\%)=363(100)[\mathrm{M}]^{+}, 194(9)[\mathrm{M}-\mathrm{ArN}]^{+}, 180(53)\left[\mathrm{M}-\mathrm{ArN}_{2}\right]^{+}$. $\mathrm{C}_{19} \mathrm{H}_{14} \mathrm{BrN}_{3}$ (364.24): calcd. C 62.65, H 3.87, N 11.54; found C 63.37, H 3.82, N 11.49.

\section{3-Methyl-2-((p-tolyl)diazenyl)-1H-benzo[g]indole (3e)}

Yield 51\%; m.p. $176-178{ }^{\circ} \mathrm{C} ;{ }^{1} \mathrm{H}$ NMR (400 MHz, $\left.\mathrm{CDCl}_{3}\right): \delta=2.75$ (s, $3 \mathrm{H}, \mathrm{CH}_{3}$ ), 2.43 (s, $\left.3 \mathrm{H},{ }^{*} \mathrm{CH}_{3}\right), 9.62$ (br. s, NH), 8.05 (d, JH,H = 7.8 Hz, $\left.1 \mathrm{H}, \mathrm{H}-10\right), 7.88$ (d, JH,H = 7.6 Hz, $1 \mathrm{H}$, $\mathrm{H}-14), 7.83$ (d, JH,H = 8.3 Hz, $\left.2 \mathrm{H}, \mathrm{H}-2 \backslash \mathrm{H}-2^{\prime}\right), 7.68$ (d, JH,H = 8.6 Hz, $\left.1 \mathrm{H}, \mathrm{H}-17\right), 7.46-7.54$ (m, $3 \mathrm{H}, \mathrm{H}-11, \mathrm{H}-15, \mathrm{H}-16), 7.30\left(\mathrm{~d}, \mathrm{JH}, \mathrm{H}=8.3 \mathrm{~Hz}, 2 \mathrm{H}, \mathrm{H}-3 \backslash \mathrm{H}-3{ }^{\prime}\right)$ ppm. ${ }^{13} \mathrm{C}$ NMR $(100.6$ $\left.\mathrm{MHz}, \mathrm{CDCl}_{3}\right): \delta=9.0\left(\mathrm{CH}_{3}\right), 21.9\left({ }^{*} \mathrm{CH}_{3}\right), 119.8(\mathrm{C}-17), 121.3(\mathrm{C}-10), 122.7\left(\mathrm{C}-2 \backslash \mathrm{C}-2^{\prime}\right), 129.5$ (C-14), 130.2 (C-3 \C-3'), 151.5 (C-5), 121.4, 121.6, 121.9, 125.2, 126.1, 126.2, 131.9, 133.3, 140.6, 145.2 ppm. MS: $m / z(\%)=299(100)[\mathrm{M}]^{+}, 194(5)[\mathrm{M}-\mathrm{ArN}]^{+}, 180(21)\left[\mathrm{M}-\mathrm{ArN}_{2}\right]^{+} . \mathrm{C}_{20} \mathrm{H}_{17} \mathrm{~N}_{3}$ (299.37): calcd. C 80.24, H 5.72, N 14.04; found C 81.12, H 5.64, N 14.17.

3-Methyl-2-((naphthalen-2-yl)diazenyl)-1H-benzo[g]indole (3f)

Yield 53\%; m.p. $174-176{ }^{\circ} \mathrm{C} ;{ }^{1} \mathrm{H}$ NMR $\left(250 \mathrm{MHz}, \mathrm{CDCl}_{3}\right): \delta=2.76$ (s, $\left.3 \mathrm{H}, \mathrm{CH}_{3}\right), 9.62$ (br. s, $\mathrm{NH}), 8.90$ (d, JH,H = 8.2 Hz, 1 H, H-7'), 8.11 (d, JH,H = 7.9 Hz, 1 H, H-10), 7.43-7.92 (m, 11 $\mathrm{H})$ ppm. ${ }^{13} \mathrm{C} \mathrm{NMR}\left(62.9 \mathrm{MHz}, \mathrm{CDCl}_{3}\right): \delta=8.8\left(\mathrm{CH}_{3}\right), 119.5(\mathrm{C}-17), 165.1(\mathrm{C}-5), 112.4,121.0$, $121.3,123.4,125.9,126.0,126.4,126.5,128.1,129.2,130.0$ ppm. MS: $m / z(\%)=335(100)[\mathrm{M}]^{+}$, 180 (42) $\left[\mathrm{M}-\mathrm{ArN}_{2}\right]^{+} . \mathrm{C}_{23} \mathrm{H}_{17} \mathrm{~N}_{3}$ (335.40): calcd. C 82.36, H 5.11, N 12.53; found C 82.25, H $5.15, \mathrm{~N} 12.3$.

\subsection{In Vitro Cytotoxicity Assay}

The cellular response to drugs was evaluated using the sulforhodamine B assay, as described in literature [31]. Briefly, the human tumor cell lines making up the NCI cancer screening panel were routinely grown in an RPMI 1640 medium containing 5\% fetal bovine serum and $2 \mathrm{mM}$ L-glutamine. The cells were inoculated into 96-well microtiter plates in $100 \mathrm{~mL}$ of the complete medium at densities ranging from 5000 to 40,000 cells/well. The microtiter plates containing cells were incubated for $24 \mathrm{~h}$ prior to the addition of experimental drugs. Following the addition of the drugs, the plates were incubated for an additional 48h, and the cells were fixed with TCA, washed, and stained with sulforhodamine B (Sigma Chemical Co., St. Louis, MO, USA) at $0.4 \%(w / v)$ in $1 \%$ acetic acid. After washing with $1 \%$ acetic acid, the stain was solubilized with $10 \mathrm{mM}$ unbuffered Tris base, and the absorbance was measured on a Bio-Tek microplate reader. Dose-response parameters were calculated, as reported in the literature [32].

\section{Conclusions}

In summary, we successfully prepared a new series of benzo[g]indoles (3a-f) following a simple, yet effective synthetic avenue, which provides several opportunities for the chemical diversification of the end products. All of the compounds ( $3 a-f)$ were characterized using spectroscopic methods. The initial in vitro cancer cell screen revealed a rather interesting cytotoxicity of some of these compounds against a few cancer cell 
lines, including leukemia, melanoma, renal, and breast cancer cell lines. Further in vivo experiments will be conducted in the future.

Author Contributions: M.M.A. participated in the synthesis part and writing of the paper, E.S.M. participated in the writing of the paper, S.A.I.A. participated in design and managing the biology part, R.S. participated in the data analysis, and R.J.A.-J. designed and supervised the whole project. All authors have read and agreed to the published version of the manuscript.

Funding: This research was funded by His Majesty Trust Fund, grant number SR/SCI/CHEM/19/01. R.J.A.-J. and R.S. would like to thank the Research School PLUS at Ruhr University of Bochum for awarding a visiting international fellowship to R.J.A.-J.

Institutional Review Board Statement: Not applicable.

Informed Consent Statement: Not applicable.

Data Availability Statement: All of the data is included in the manuscript.

Acknowledgments: In memoriam of our teacher, a great scientist and best friend, Prof. Dr. h. c. Wolfgang Voelter (1936-2021).

Conflicts of Interest: The authors declare no conflict of interest.

\section{References}

1. Li, L.; Qian, Y.; Sun, L.; Han, F.Y.; Zhang, R.; Wang, P.Y.; Xu, Z.P. Albumin-stabilized layered double hydroxide nanoparticles synergized combination chemotherapy for colorectal cancer treatment. Nanomed. Nanotechnol. Biol. Med. 2021, $34,102369$. [CrossRef]

2. Calabresi, P.; Chabner, B.A. Goodmann E Gillman's Pharmacological Basis of Therapeutics, 12th ed.; McGraw-Hill: New York, NY, USA, 2011.

3. Borthakur, M.; Gogoi, S.; Gogoi, J.; Boruah, R.C. Lewis acid catalyzed rapid synthesis of 5-hydroxy-benzo [g] indole scaffolds by a modified Nenitzescu reaction. Tetrahedron Lett. 2010, 51, 5160-5163. [CrossRef]

4. Moghadam, E.S.; Hamel, E.; Shahsavari, Z.; Amini, M. Synthesis and anti-breast cancer activity of novel indibulin related diarylpyrrole derivatives. DARU J. Pharm. Sci. 2019, 27, 179-189. [CrossRef]

5. Gribble, G.W. Recent developments in indole ring synthesis-Methodology and applications. J. Chem. Soc. Perkin Trans. 2000, 7, 1045-1075. [CrossRef]

6. Gribble, G.W. Novel chemistry of indole in the synthesis of heterocycles. Pure Appl. Chem. 2003, 75, 1417-1432. [CrossRef]

7. Agarwal, S.; Cammerer, S.; Filali, S.; Frohner, W.; Knoll, J.; Krahl, M.P.; Reddy, K.R.; Knolker, H.J. Novel routes to pyrroles, indoles and carbazoles-applications in natural product synthesis. Curr. Org. Chem. 2005, 9, 1601-1614. [CrossRef]

8. Humphrey, G.R.; Kuethe, J.T. Practical methodologies for the synthesis of indoles. Chem. Rev. 2006, 106, 2875-2911. [CrossRef]

9. Inman, M.; Moody, C.J. Indole synthesis-something old, something new. Chem. Sci. 2013, 4, 29-41. [CrossRef]

10. Adams, D.; Bénardeau, A.; Bickerdike, M.J.; Bentley, J.M.; Bissantz, C.; Bourson, A.; Cliffe, I.A.; Hebeisen, P.; Kennett, G.A.; Knight, A.R.; et al. 5-HT2C receptor agonists for the treatment of obesity. Biological and chemical adventures. CHIMIA Int. J. Chem. 2004, 58, 613-620. [CrossRef]

11. Nishino, H.; Murakoshi, M.; Mou, X.Y.; Wada, S.; Masuda, M.; Ohsaka, Y.; Satomi, Y.; Jinno, K. Cancer prevention by phytochemicals. Oncology 2005, 69, 38-40. [CrossRef] [PubMed]

12. Bruno, F.; Errico, S.; Pace, S.; Nawrozkij, M.B.; Mkrtchyan, A.S.; Guida, F.; Maisto, R.; Olgaç, A.; D'Amico, M.; Maione, S.; et al. Structural insight into the optimization of ethyl 5-hydroxybenzo [g] indol-3-carboxylates and their bioisosteric analogues as 5-LO/m-PGES-1 dual inhibitors able to suppress inflammation. Eur. J. Med. Chem. 2018, 155, 946-960. [CrossRef] [PubMed]

13. Faust, R.; Garratt, P.J.; Jones, R.; Yeh, L.K.; Tsotinis, A.; Panoussopoulou, M.; Calogeropoulou, T.; Teh, M.T.; Sugden, D. Mapping the melatonin receptor. 6. Melatonin agonists and antagonists derived from $6 \mathrm{H}$-isoindolo [2,1-a] indoles, 5, 6-dihydroindolo [2,1-a] isoquinolines, and 6,7-dihydro-5 H-benzo [c] azepino [2,1-a] indoles. J. Med. Chem. 2000, 43, 1050-1061. [CrossRef] [PubMed]

14. Jiang, F.; Wei, Q.; Li, H.; Li, H.; Cui, Y.; Ma, Y.; Chen, H.; Cao, P.; Lu, T.; Chen, Y. Discovery of novel small molecule induced selective degradation of the bromodomain and extra-terminal (BET) bromodomain protein BRD4 and BRD2 with cellular potencies. Bioorg. Med. Chem. 2020, 28, 115181. [CrossRef]

15. Yasuda, D.; Yuasa, A.; Obata, R.; Nakajima, M.; Takahashi, K.; Ohe, T.; Ichimura, Y.; Komatsu, M.; Yamamoto, M.; Imamura, R.; et al. Discovery of benzo [g] indoles as a novel class of non-covalent Keap1-Nrf2 protein-protein interaction inhibitor. Bioorg. Med. Chem. Lett. 2017, 27, 5006-5009. [CrossRef]

16. Peduto, A.; Krauth, V.; Collarile, S.; Dehm, F.; Ambruosi, M.; Belardo, C.; Guida, F.; Massa, A.; Esposito, V.; Maione, S.; et al. Exploring the role of chloro and methyl substitutions in 2-phenylthiomethyl-benzoindole derivatives for 5-LOX enzyme inhibition. Eur. J. Med. Chem. 2016, 108, 466-475. [CrossRef] 
17. Dias, F.R.; Guerra, F.S.; Lima, F.A.; de Castro, Y.K.; Ferreira, V.F.; Campos, V.R.; Fernandes, P.D.; Cunha, A.C. Synthesis and Biological Evaluation of Benzo [f] indole-4,9-diones N-Linked to Carbohydrate Chains as New Type of Antitumor Agents. J. Braz. Chem. Soc. 2021, 32, 476-489. [CrossRef]

18. Pappa, G.; Lichtenberg, M.; Iori, R.; Barillari, J.; Bartsch, H.; Gerhäuser, C. Comparison of growth inhibition profiles and mechanisms of apoptosis induction in human colon cancer cell lines by isothiocyanates and indoles from Brassicaceae. Mutat. Res. Fundam. Mol. Mech. Mutagenes. 2006, 599, 76-87. [CrossRef]

19. Koeberle, A.; Haberl, E.M.; Rossi, A.; Pergola, C.; Dehm, F.; Northoff, H.; Troschuetz, R.; Sautebin, L.; Werz, O. Discovery of benzo [g] indol-3-carboxylates as potent inhibitors of microsomal prostaglandin E2 synthase-1. Bioorg. Med. Chem. 2009, 17, 7924-7932. [CrossRef] [PubMed]

20. Gach, K.; Modranka, J.; Szymański, J.; Pomorska, D.; Krajewska, U.; Mirowski, M.; Janecki, T.; Janecka, A. Anticancer properties of new synthetic hybrid molecules combining naphtho [2,3-b] furan-4, 9-dione or benzo [f] indole-4,9-dione motif with phosphonate subunit. Eur. J. Med. Chem. 2016, 120, 51-63. [CrossRef] [PubMed]

21. Wurm, G.; Baumann, J.; Geres, U.; Schmidt, H. Lipophilic naphthols and 1,4-naphthoquinones as inhibitors of prostaglandin synthesis. 6. Study of 1,4-naphthoquinones. Arzneim. Forsch. 1984, 34, 652-658.

22. Singh, W.M.; Dash, B.C. Synthesis of some new Schiff bases containing thiazole and oxazole nuclei and their fungicidal activity. Pesticides 1988, 22, 33-37.

23. El-masry, A.H.; Fahmy, H.H.; Ali Abdelwahed, S.H. Synthesis and antimicrobial activity of some new benzimidazole derivatives Molecules 2000, 5, 1429-1438. [CrossRef]

24. Gomha, S.M.; Salah, T.A.; Abdelhamid, A.O. Synthesis, characterization, and pharmacological evaluation of some novel thiadiazoles and thiazoles incorporating pyrazole moiety as anticancer agents. Mon. Chem. Chem. Mon. 2015, 146, 149-158. [CrossRef]

25. Tevyashova, A.N.; Olsufyeva, E.N.; Turchin, K.F.; Balzarini, J.; Bykov, E.E.; Dezhenkova, L.G.; Shtil, A.A.; Preobrazhenskaya, M.N. Reaction of the antitumor antibiotic olivomycin I with aryl diazonium salts. Synthesis, cytotoxic and antiretroviral potency of 5-aryldiazenyl-6-O-deglycosyl derivatives of olivomycin I. Bioorg. Med. Chem. 2009, 17, 4961-4967. [CrossRef]

26. Dougan, S.J.; Melchart, M.; Habtemariam, A.; Parsons, S.; Sadler, P.J. Phenylazo-pyridine and phenylazo-pyrazole chlorido ruthenium (II) arene complexes: Arene loss, aquation, and cancer cell cytotoxicity. Inorg. Chem. 2006, 45, 10882-10894. [CrossRef]

27. Shoemaker, R.H. The NCI60 human tumour cell line anticancer drug screen. Nat. Rev. Cancer 2006, 6, 813-823. [CrossRef]

28. Pinna, G.A.; Loriga, G.; Murineddu, G.; Grella, G.; Mura, M.; Vargiu, L.; Murgioni, C.; La Colla, P. Synthesis and anti-HIV-1 activity of new delavirdine analogues carrying arylpyrrole moieties. Chem. Pharm. Bull. 2001, 49, 1406-1411. [CrossRef]

29. Chacón-García, L.; Martínez, R. Synthesis and in vitro cytotoxic activity of pyrrolo [2,3-e] indole derivatives and a dihydro benzoindole analogue. Eur. J. Med. Chem. 2002, 37, 261-266. [CrossRef]

30. Oslund, R.C.; Cermak, N.; Gelb, M.H. Highly specific and broadly potent inhibitors of mammalian secreted phospholipases A2. J. Med. Chem. 2008, 51, 4708-4714. [CrossRef] [PubMed]

31. Moghadam, E.S.; Tehrani, M.H.; Csuk, R.; Fischer, L.; Faramarzi, M.A.; Rashidi, A.; Javadi, I.; Amini, M. 2,4-Disubstituted Quinazoline Derivatives Act as Inducers of Tubulin Polymerization: Synthesis and Cytotoxicity. Anti-Cancer Agents Med. Chem. 2019, 19, 1048-1057. [CrossRef] [PubMed]

32. Hong, B.C.; Jiang, Y.F.; Chang, Y.L.; Lee, S.J. Synthesis and Cytotoxicity Studies of Cyclohepta [b] indoles, Benzo [6,7] Cyclohepta [1,2-b] Indoles, Indeno [1,2-b] Indoles, and Benzo [a] Carbazoles. J. Chin. Chem. Soc. 2006, 53, 647-662. [CrossRef] 